\title{
Author Correction: PD-L1 blockade in combination with inhibition of MAPK oncogenic signaling in patients with advanced melanoma
}

\author{
Antoni Ribas (D), Alain Algazi (D), Paolo A. Ascierto (1D, Marcus O. Butler (D), Sunandana Chandra, Michael Gordon, \\ Leonel Hernandez-Aya, Donald Lawrence, Jose Lutzky (D), Wilson H. Miller Jr, Katie M. Campbell (D), \\ Bruno Delafont, Shannon Marshall, Nancy Mueller \& Caroline Robert
}

Correction to: Nature Communications https://doi.org/10.1038/s41467-020-19810-w, published online 7 December 2020

There was an error in the original version of this Article. A table describing the patient characteristics and the sample collection was not included in the paper. This table is now included as Supplementary Data 1 and the first sentence of the Results section has been amended to state 'Between December 2013 and April 2015, 99 patients were screened. Sixty-eight patients were enrolled from 11 study centers (Supplementary Fig. 1, Supplementary Data 1), with 31 patients subsequently excluded due to screening failures'. The PDF and HTML versions of the Article have been updated.

Published online: 12 August 2021

\section{Additional information}

Supplementary information The online version contains supplementary material available at https://doi.org/10.1038/s41467-021-25285-0.

\footnotetext{
(c) (i) Open Access This article is licensed under a Creative Commons Attribution 4.0 International License, which permits use, sharing, adaptation, distribution and reproduction in any medium or format, as long as you give appropriate credit to the original author(s) and the source, provide a link to the Creative Commons license, and indicate if changes were made. The images or other third party material in this article are included in the article's Creative Commons license, unless indicated otherwise in a credit line to the material. If material is not included in the article's Creative Commons license and your intended use is not permitted by statutory regulation or exceeds the permitted use, you will need to obtain permission directly from the copyright holder. To view a copy of this license, visit http://creativecommons.org/licenses/by/4.0/.
}

(c) The Author(s) 2021 